\title{
SIX SIGMA METHODOLOGY IMPLEMENTED IN AUTOMOTIVE INDUSTRY
}

\author{
Goran Despinoski \\ Faculty of Electrical Engineering and Information Technologies, \\ "Ss. Cyril and Methodius" University in Skopje, \\ P.O. box 574, 1001 Skopje, N. Macedonia \\ goran.despinoski@gmail.com
}

\begin{abstract}
A b s t r a c t : In present era of competition, Six Sigma has been considered as a powerful business strategy that employs a well structured continuous improvement methodology to reduce rejections within the manufacturing processes using effective application of statistical tools and techniques. This paper presents the implementation of Sixsigma methodology for reducing rejection of automobile part in an industry. The DMAIC (Define, Measure, Analyze, Improve and Control) methodology has been used to achieve quality level. During this process, data for all possible causes were collected, analyzed and thereby conclusions were drawn. Implementation of Six Sigma resulted in reduction of rejection and improvement of process capability and process performance. Finally, implementation of Six-sigma methodology has resulted in increase in quality level of assembly line and pre-assembly process in automobile company.
\end{abstract}

Key words: Six Sigma; Define; Measure; Analyze; Improve and Control (DMAIC); Lean Six Sigma (LSS); Statistical process control (SPC); Measurement system analyze (MSA)

\section{МЕТОДОЛОГИЈАТА ШЕСТ СИГМА ИМПЛЕМЕНТИРАНА ВО АВТОМОБИЛСКАТА ИНДУСТРИЈА}

\begin{abstract}
А п с т р а к т: Во денешната ера на конкуренција, „Шест Сигма“ се смета за моќна бизнис-стратегија што користи добро структурирана метологија за континуирано подобрување, со цел да ги намали дефектите во процесот на призводство применувајќи ефективни статистички алатки и техники. Во овој труд е прикажано имплементирањето на методологијата „Шест Сигма“ за намалување на дефекти во автомобилската индуструја. Се користи методологијата DMAIC (Дефинирај, Мери, Анализирај, Подобри и Контролирај) за да се постигне бараниот квалитет. За време на овој процес се собрани податоци за сите можни причинители на појавата на дефекти, и добиените податоци се анализирани и донесен е заклучок. Имплементирањето на „Шест Сигма“ во автомобилската компанија, што е предмет на ова истражување, резултира со намалување на стапката на дефекти. т.е подобрување на чподготбеноста перформансот на процесот. Заклучно, имплементирањето на методологијата „Шест Сигма“ резултира со зголемување на нивото на квалитетот на линијата за финално монтирање и на процесот на подготовка во производниот процес на автомобилската компанија што е предмет на истражувањето.
\end{abstract}

Клучни зборови: Шест Сигма; дефинирај, мери, анализирај, подобри и контролирај (DMAIC); статистичка контрола на процес (SPC); анализа на мерните системи (MSA)

\section{INTRODUCTION}

For automotive industry to be globally competitive operational excellence is the basic success mantra. For global competiveness many technique such as Quality circles, Total quality management, ISO certifications are being tried. The automotive sector needs advance strategy which can have multidirectional benefit in shorter duration [1].
Six Sigma DMAIC is excellent methodology that is fully integrated into all aspects of the automotive manufacturing processes, and is now recognized worldwide as the standard of quality that must be used to be recognized as a world-class level manufacturing process [2].

Six Sigma DMAIC is designed to reduce process variation by defining, measuring, analyzing, improving and controlling processes [3]. 
The practitioners and researchers of Six Sigma have provided multiple dimensions and interpretations of this methodology. It is a business strategy to improve the effectiveness and efficiency of all the operations [4].

There are many frameworks proposed by different researcher in combination with other quality initiatives in disparate context. Some of them explores the study of the combination of two distinct strategies, Six Sigma and Theory of Constraints (TOC), for improving manufacturing system performance [5]. Some study also focus and introduce a conceptual framework that discuss the relationship between the two fields of the organizational discipline represented by Six Sigma and innovation from the perspective of the Absorptive Capacity Theory [6]. Increasingly, organizations that use Six Sigma are making an effort to integrate lean into their existing process improvement framework [7]. It is spotlighted on Six Sigma Process Improvement Model, where the goal of the process is to improve the overall quality of the system under development [8]. Studies also focus on the guiding principles of the Shainin tools [9] which are powerful, and at least, in combination, unique.

The approach that will be analyzed in this paper is integration of Lean Tool intelligent automation in improve phase of Six Sigma DMAIC (Define, Measure, Analyze, Improve and Control).

\section{TEORETICAL PART - SIX SIGMA (DMAIC) METHODOLOGY}

In the Table 1 are presented implementation phases of the Six Sigma (DMAIC) methodology [10].

When implementing the DMAIC method, a number of auxiliary quality improvement tools and methods are used. The improvement cycle using the DMAIC method consists of the following elements [11]:

Six Sigma (DMAIC) - Define phase: This phase will involves creating a project chapter, scope of the project and identifying projects critical to quality characteristics (CTQs). Select an opportunity for improvement and define the problem.

Six Sigma (DMAIC) - Measure phase: The major activity in measure phase is the project base lining. This includes identification of measurement factors, which need to improve the project Critical to Quality (CTQ) characteristics, developing "as is" process map, analyzing variations in the measurement system (MSA), preparing data collection plan, and calculations of standard deviation $\sigma$ [St Dev], Process Capability Index [Cpk] and Process Performance Index [Ppk].

Table 1

\section{Implementation phases of Six Sigma (DMAIC)}

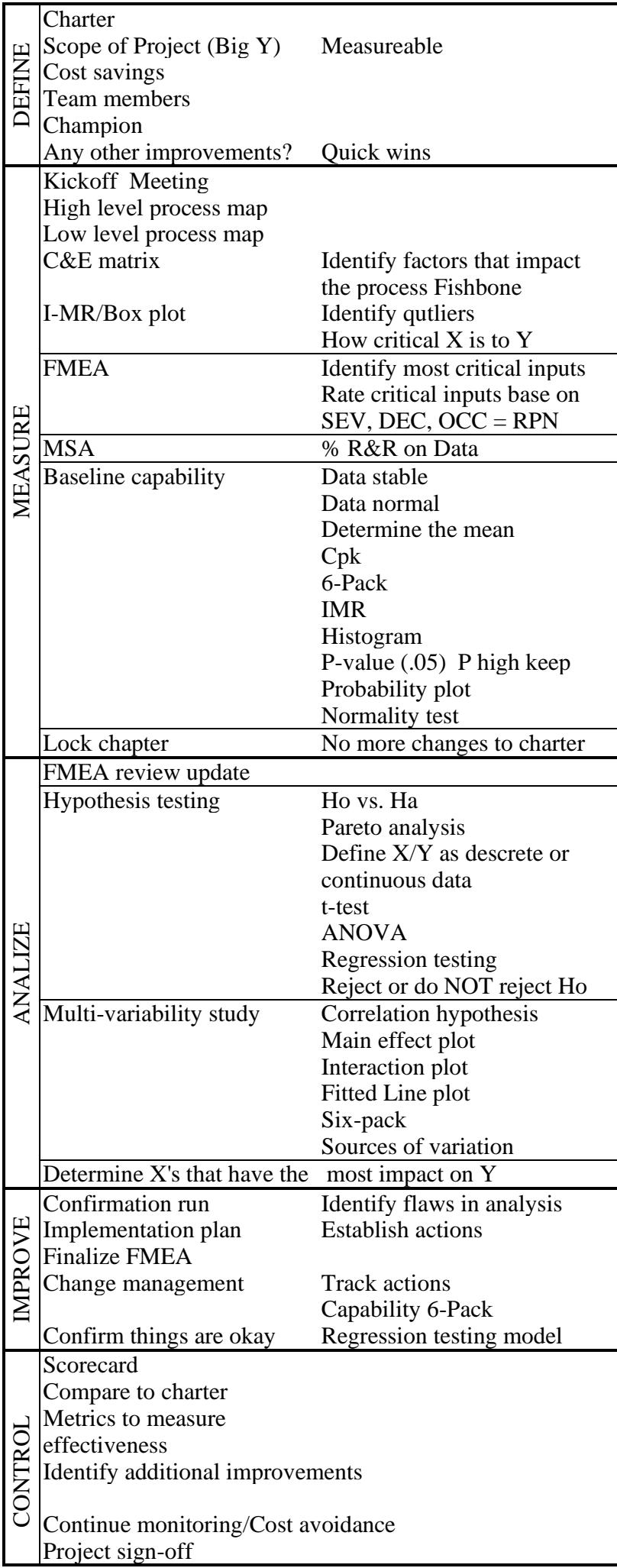


Measurement system analysis (MSA): MSA is defined as an experimental and mathematical method of determining the amount of variation that exists within a measurement process. Variation in the measurement process can directly contribute to our overall process variability. MSA is used to certify the measurement system for use by evaluating the system's accuracy, precision and stability [14].

Observed process variations is composed of true process variations and measurement system variations:

$$
\sigma_{\mathrm{opv}}^{2}=\sigma_{\mathrm{tpv}}^{2}+\sigma_{\mathrm{msv}}^{2},
$$

where $\sigma$ is normal distribution, $\sigma_{\mathrm{opv}}$ is observed process variations, $\sigma_{\mathrm{tpv}}$ is true process variations and $\sigma_{\mathrm{mv}}$ is measurement system variations.

In minitab software which we will use in experimental part of this paper for data analyses and statistical \& process improvements, symbol for observed process variations $\left(\sigma_{\mathrm{opv}}\right)$ is TV-total variations, symbol for true process variations $\left(\sigma_{\mathrm{tpv}}\right)$ is PV - part-to part variations and symbol for measurement system variations ( $\left.\sigma_{\mathrm{ms}}\right)$ is Gage $\mathrm{R} \& \mathrm{R}$ or simply GRR (Gage repeatability \& reproducibility):

$$
T V^{2}=P V^{2}+G R R^{2} .
$$

In the further theoretical part of this paper we will use Minitab symbols in order to coincide with symbols in experimental part were we calculate baseline (MSA study and Statistical process control with control charts).

For validation of the measurement process is used Gage R\&R or GRR study to assess the accuracy, precision and stability. Gage $R \& R$ study is a standard tool to assess and quantify the capability of a measurement system that generates continuous (variable) data on items that can be repeatedly measured. The key question that MSA seeks to answer is, can the data be trusted. Quality of the measurement system is characterized by statistical properties. For reliable Gage R\&R study number of individual measurements should be: $[\mathrm{S}] \times[\mathrm{O}] \times[\mathrm{T}]$ $>30$ ( $\mathrm{S}$ - sample, $\mathrm{O}$ - operators, and $\mathrm{T}$ - trials). Samples for MSA study should span at least $80 \%$ of the full, typical range of the process in order to evaluate linearity, which is consistency of the measurement across the entire range of the measuring gage.

Components of variation graph in minitab: This is chart with various components of variation, based on \% Contribution, \% Study variation (or $\mathrm{R} \& \mathrm{R} \%$ - ratio for reputability and reproducibility, see formula 8 ) and \%Tolerance (or $\mathrm{P} / \mathrm{T} \%$ ratio of precision to tolerance, see formula 9). The different components of the graph are:

Repeatability. These are variations in the measurement system "within appraiser", that occurs between successive measurements of the same sample, same characteristic, by the same person using the same instrument. This variation is usually referred to as Equipment Variation (EV) in the Gage R\&R study.

Equipment variations (EV) is calculated by multiplication of average ranges between appraisers $\overline{\bar{R}}$ and constant $K_{1}$ which depends upon number of trials used in Gage study (see Table A-2, Appendix):

$$
E V=\overline{\bar{R}} \times K_{1} .
$$

Reproducibility. These are variations "between appraisers" or "appraiser variations AV", that occur when different conditions are used to make the measurements: different person, different setup, different samples and different environmental conditions. Since the appraiser variation is contaminated by the equipment variation, it must be adjusted by subtracting a fraction of the equipment variation. Therefore, the appraiser variation (AV) is calculated by:

$$
A V=\sqrt{\left(\bar{X}_{\mathrm{DIFF}} \cdot K_{2}\right)^{2}-\left(E V^{2} /(n r)\right)}
$$

where $K_{2}$ is constant which depends upon number of appraisers, $n$ is number of parts and $r$ is number of trials (see Table A-2, Appendix):

$$
\bar{X}_{D I F F}=[\max \bar{X}]-[\min \bar{X}],
$$

where: $\bar{X}_{\mathrm{DIFF}}$ is subtracting max average of measurements by appraiser and min average of measurements by appraiser (see Table A-1 in Appendix).

Gage $R \& R$ (Gage repeatability and reproducibility). When Gage $\mathrm{R} \& \mathrm{R}<10 \%$, this shows that observed process variations are not due to measurement system variations but due to the true process variations (see formula 1). The measurement system variation for repeatability and reproducibility (GRR or $\sigma_{\mathrm{ms}}$ ) is calculated by adding the square of the equipment variation and the square of the appraiser variation, and taking the square root as follows:

$$
\boldsymbol{\sigma}_{\mathrm{ms}}(\text { or } G R R)=\sqrt{(E V)^{2}+(A V)^{2}} .
$$

Part-to-part variation. The variability in measurements across different part. Ideally this should be the highest graph for a very good GR\&R 
study. Part-to-part variation (PV) are true process variations $\left(\sigma_{\mathrm{tpv}}\right)$ without measurement system variations (GRR or $\sigma_{\mathrm{ms}}$ ). PV is determined by multiplying the range of part averages $\left(R_{\mathrm{p}}\right)$ by a constant $K_{3}$. Constant $K_{3}$ depends upon the number of parts used in the GRR study and is the inverse of constant $d_{2}^{*}$ [14].

$$
P V=R_{p} \times K_{3}
$$

- \% R\&R (ratio of repeatability \& reproducibility) present measurement system variations compared with observed process variations:

$$
\mathrm{R} \& \mathrm{R} \%=\frac{\boldsymbol{\sigma}_{m s}}{\boldsymbol{\sigma}_{\text {opv }}} \cdot 100 \%=\frac{G R R}{T V} \cdot 100 \% ;
$$

where for GRR see formula 6 , and for TV see formula 2.

- P/T\% (ratio of precision to tolerance) Measurement system variations compared with tolerance:

$$
\mathrm{P} / \mathrm{T} \%=\frac{6 * \sigma_{m s}}{\text { Tolerance }} \cdot 100 \%=\frac{6 * G R R}{U S L-L S L} \cdot 100 \%,
$$

where USL is upper specification limit and LSL is lower specification limit.

Xbar chart by operators graph: This graph indicates out of control conditions. We wish to see the majority of the points on this chart outside the control limits. This indicates more sample-tosample variability (true process variations), which is desired, compared to the variability within the measurement system. The pattern between operators should be similar, if the patterns are not similar, that probably indicates a reproducibility issue.

The R chart (range) by operators graph: The range chart should be in control if the operators measure consistently. Repeatability may be questioned if the range chart is out-of-control. If the ranges for all operators are out-of-control the system is likely sensitive to operator technique. The method should be investigated if the range for one operator is out-of-control and for the other operators is in control.

Measurement by operator's graph: Shows whether differences between operators are small compared to the differences between parts.

Part * operator interaction graph: Shows whether the lines that connect the measurements from each operator are similar or whether the line cross each other. Lines that are not parallel or that cross indicates that an operator's ability to measure a part consistently depends on which part is being measured. A line that is consistently higher or lower than the others indicates that an operator adds bias to the measurement by consistently measuring high or low.

Validation of measurement system: Excellent measurement systems have both of ratios GRR (R\&R \% and P/T \%) less then $10 \%$. In that case observed process variations are not caused by measurement system variations, they are result of true process variations.

Statistical process control (SPC): SPC is a procedure for open or closed loop control of manufacturing processes, based on statistical methods. Random samples of parts are taken from the manufacturing process according to process specific sampling rules [15]. Process characteristics are measured and entered in control charts. SPC and control charts are necessary tool in measurement phase of DMAIC to establish a process baseline [16]. The process baseline is an essential part of DMAIC, because this baseline is later compared to the improved process to demonstrate the project improvement results.

A variable control chart can explain process data in terms of its process variations, piece-to-piece variation, and its process average. Because of this, control charts for variables are usually prepared and analyzed in pairs.

An individuals and moving range chart $(X-$ $\mathrm{MR}$ ) is a pair of control charts for processes with a subgroup size of one. Used to determine if a process is stable and predictable, it creates a picture of how the system changes over time. The individual (X) chart displays individual measurements. The moving range (MR) chart shows variability between one data point and the next. Individuals and moving range charts are also used to monitor the effects of process improvement theories.

Individual control chart: Average of individual values of the measured samples:

$$
\bar{X}=\frac{\left(X_{1}+X_{2}+\cdots+X_{\mathrm{k}}\right)}{k} .
$$

Upper control limit of the iIndividual chart:

$$
U C L_{X}=\bar{X}+E_{2} \bar{R} .
$$

where $E_{2}$ is constant, $\bar{R}$ is average range, $\bar{X}$ is average of individual measurements [15].

Lower control limit of the individual chart:

$$
L C L_{X}=\bar{X}-E_{2} \bar{R} .
$$

Moving range control chart:

$$
\overline{M R}=\frac{\left(M R_{2}+M R_{3}+\cdots+M R_{k}\right)}{k-1} .
$$


where MR is variability/range between one data point and next.

Upper control limit of the moving range control chart:

$$
U C L_{R}=D_{4} \bar{R},
$$

where $D_{4}$ is constant, $\bar{R}$ is average range [15].

Lower control limit of the moving range chart:

$$
L C L_{R}=D_{3} \bar{R}
$$

where $D_{3}$ is constant.

Process capability within subgroup variation $\left(\sigma_{\mathbf{c}}\right)$. This is the variation due only to the variation within the subgroups. If the process is in statistical control, this variation is a good estimate of the inherent process variation. It can be estimate from the standard deviation formula:

$$
\widehat{\sigma} \mathrm{c}=\overline{\mathrm{R}} / d_{2} .
$$

where $d_{2}$ is constant, $\overline{\mathrm{R}}$ is average range from the individual measurements [15].

Process capability $(\boldsymbol{C p})$, it takes in consideration only process variations within subgroups. It compares the process capability to the maximum allowable variation as indicates by the tolerance. $C P$ is not impacted by the process location.

$$
C_{p}=\frac{U S L-L S L}{6 \sigma_{c}}=\frac{U S L-L S L}{6\left(\overline{\mathrm{R}} / d_{2}\right)} .
$$

$C p_{k}$ (process capability index): It takes the process location as well as the capability into account. For bilateral tolerances $C p_{k}$ will always be less or equal to $C p$.

$$
C p_{k}=\min \left\{\left(\frac{U S L-\overline{\bar{X}}}{3\left(\overline{\mathrm{R}} / d_{2}\right)}\right),\left(\frac{\overline{\bar{X}}-L S L}{3\left(\overline{\mathrm{R}} / d_{2}\right)}\right)\right\} .
$$

$C p_{k}$ and $C p$ should always be evaluated and analyzed together. A $C p$ value significantly greater than the corresponding $C p_{k}$ indicates an opportunity for improvement by centering the process.

\section{Process performance}

Total process variations. This is the variation due to both within subgroup variation and between subgroup variations. This variation may be estimated by s, the sample standard deviation:

$$
s=\sqrt{\sum_{i}^{n} \frac{\left(X_{i}-\bar{X}\right)^{2}}{n-1}}
$$

Process performance $(P p)$ : It takes in consideration total process variations. It compares the process performance to the maximum allowable variation as indicates by the tolerance. $P_{p}$ is not impacted by the process location.

$$
P p=\frac{U S L-L S L}{6 s}=\frac{U S L-L S L}{\sqrt[6]{\sum_{i}^{n} \frac{\left(x_{i}-\bar{X}\right)^{2}}{n-1}}} .
$$

$P_{p k}$ (process performance index): It takes the process location as well as the performance into account. For bilateral tolerances $P p_{\mathrm{k}}$ will always be less or equal to $P p$.

$P p_{k}=\min \left\{\left(\frac{U S L-\bar{X}}{3 \sqrt{\sum_{i}^{n} \frac{\left(x_{i}-\bar{X}\right)^{2}}{n-1}}}\right),\left(\frac{\overline{\bar{X}}-L S L}{3 \sqrt{\sum_{i}^{n} \frac{\left(X_{i}-\bar{X}\right)^{2}}{n-1}}}\right)\right\}$.

$P_{p k}$ and $P_{p}$ should always be evaluated and analyzed together. A $P_{p}$ value significantly greater than the corresponding $P_{p k}$ indicates an opportunity for improvement by centering the process.

Six Sigma (DMAIC) - Analyze phase: The analyze phase of DMAIC helps project teams identify problems in the production process that cause product defects. This phase of Six Sigma methodology is loaded with tools to help spot the problems in the production process and to determine if these problems are the root causes of defects [17, 18]. The tools that will be used are: Pareto chart, Cause \& effect diagram, 5-why analysis, and PFMEA (process failure mode and effect analysis) [19].

Six Sigma (DMAIC) - Improve phase: The improving phase focuses on identification of the best solution to eliminate the root causes or minimize the effect of root causes [20]. Counter measure matrix will be prepared and check the effectiveness of the countermeasure actions.

Six Sigma (DMAIC) - Control phase: In the control phase, the process performance is evaluated after the implementation of the solutions, and compared with that at the start of the project. The achieved improvements are verified. The steps are taken to ensure that the improvements will be sustained in the process [21]. To ensure those activities following tools are used: PFMEA (Process failure mode and effect analysis), control plan, drafting process procedure, training, calculation of process capability and introducing SPC based on defined measuring method in control plan [22]. 


\section{EXPERIMENTAL PART - SIX SIGMA IN AUTOMOTIVE COMPANY}

Six Sigma (DMAIC) - Define phase:

Problem statement - Data collection in the period of September 2017 - September 2018 indicates that $6.400 \mathrm{ippm}$ of the seat heaters are with failure resistance out of specification, generating annual scrap costs of 235.000 euro. Process capability index is $C_{p k}=0.83(<1.33)$.

\section{Six Sigma (DMAIC) - Measure phase:}

Measurement system analysis (MSA): For the Gage R\&R study were conducted 90 measurements: $[\mathrm{S}] \times[\mathrm{O}] \times[\mathrm{T}]=90$ (see Table A-1 in Appendix). Control charts for MSA study are presented in Figures $1-5$.

Components of variation graph: Measurement system variations compared with observed process variations are $\% \mathrm{R} \& \mathrm{R}=8.26 \%$ and measurement system variations compared with tolerances are $\% \mathrm{P} / \mathrm{T}=4.22 \%$, which in both cases is less then $10 \%$ (see Formulas 8 and 9). Part-to-part variations (true process variations) are the highest graph in components of variations control chart (Figure 1).

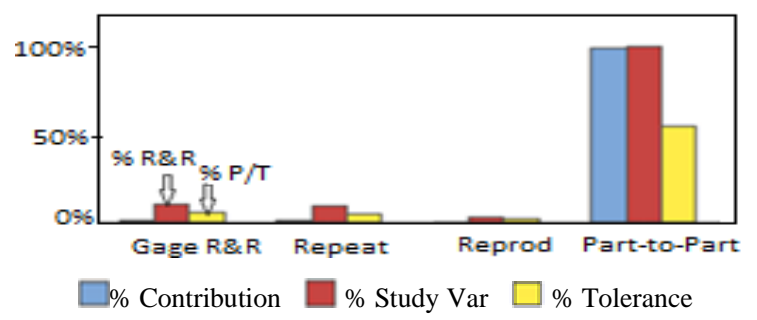

Fig. 1. Validation of measuring system (Components of variation)

Table 2

Gage evaluation table

\begin{tabular}{|c|c|c|c|c|}
\hline Source & $\begin{array}{l}\text { Std } \\
\text { Var } \\
(\mathrm{SD})\end{array}$ & $\begin{array}{c}\text { Study } \\
\text { Var } \\
(6 \times \mathrm{SD})\end{array}$ & $\begin{array}{c}\% \text { Study } \\
\text { Var } \\
(\% \mathrm{SV})\end{array}$ & $\begin{array}{l}\text { \% Tolerancc } \\
\text { (SV/Toler) }\end{array}$ \\
\hline $\begin{array}{l}\text { Total gage } \\
\text { (R\&R) }\end{array}$ & 5,1996 & 31,198 & 8.26 & 4.22 \\
\hline $\begin{array}{l}\text { Repeatability } \\
\text { (EV) }\end{array}$ & 4,8644 & 29,186 & 7.73 & 3.94 \\
\hline $\begin{array}{l}\text { Reproducibility } \\
\text { (AV) }\end{array}$ & 1,8368 & 11,021 & 2.92 & 1.49 \\
\hline Part-to-part & 62.7371 & 376.423 & 99.71 & 50.87 \\
\hline Total variation & 62.9522 & 377.713 & 100 & 51.04 \\
\hline
\end{tabular}

The conclusion of the conducted MSA study is that observed process variations are not caused by measurement system variations, they are result of true process variations. Further focus should be on process improvements in order to reduce process variations.

Xbar chart by operators: In this control chart majority of the points on the chart are outside the control limits, which indicates more sample to sample variations (true process variations), which is desired compared with measurement system variations. The patterns are similar, which indicates good reproducibility (AV) (Figure 2).

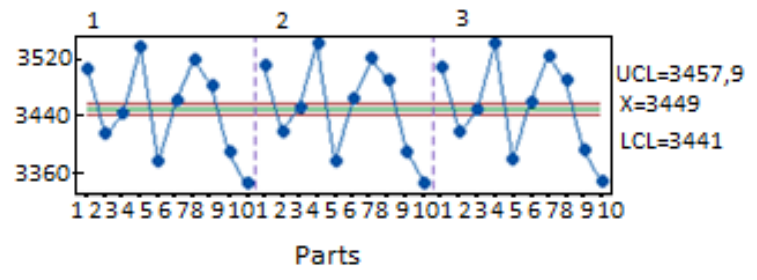

Fig. 2. Validation of measuring system (Xbar chart by operators)

R chart (range) by operators: This control chart is in control which means repeatability or EV of the operators is good (Figure 3).

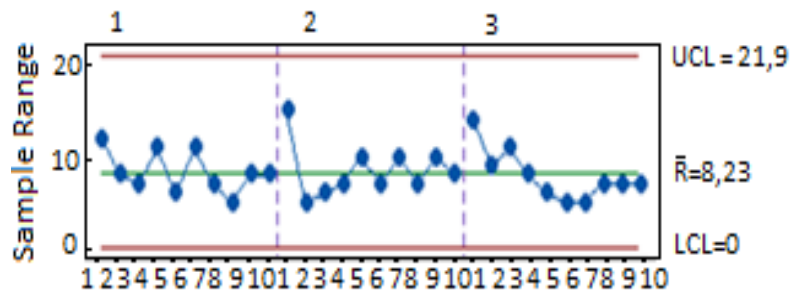

Fig. 3. Validation of measuring system ( $\mathrm{R}$ chart by operators)

Measurement by operators graph: This graph shows that differences between operators (AV) are small compared to the differences between parts (PV or true process variations) (Figure 4).

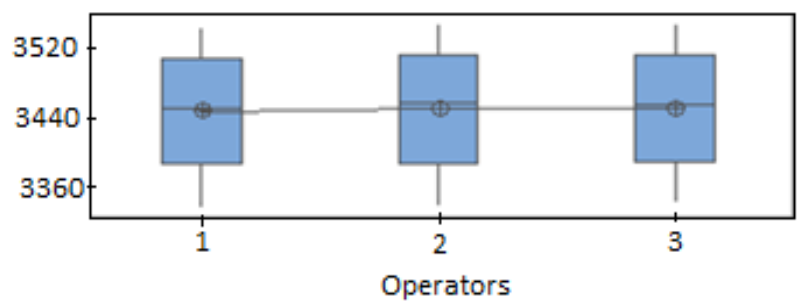

Fig . 4. Validation of measuring system (Measurements by operators) 
Part * Operator interaction (see Figure 5):

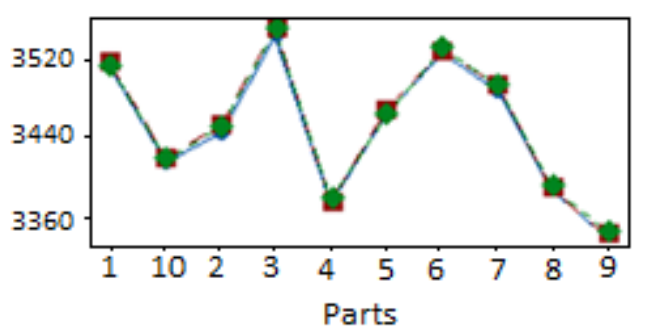

Fig. 5. Validation of measuring system (Part* Operators iInteraction)

In this graph lines coincident which indicates that the operators measure similarly. Operator does not add bias.

Statistical process control (SPC): In this paper subgroup size is one, which means that we will use individuals and moving range (X-MR) pair of control charts.

The individual $(\mathrm{X})$ chart displays individual measurements. The moving range (MR) chart shows variability between one data point and the next (see Figures 6-9).

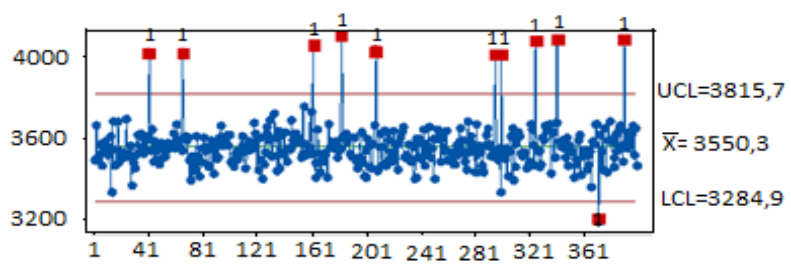

Fig. 6. Process capability graph (current process): I chart (individual value)

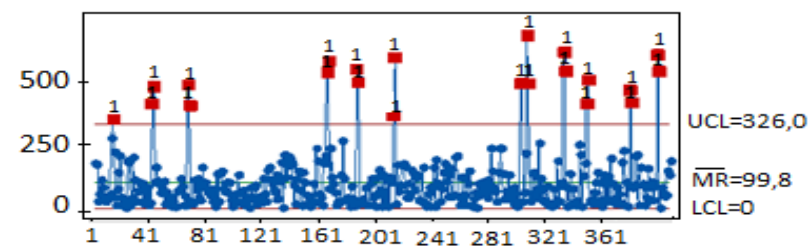

Fig. 7. Process capability graph (current process): Moving range chart

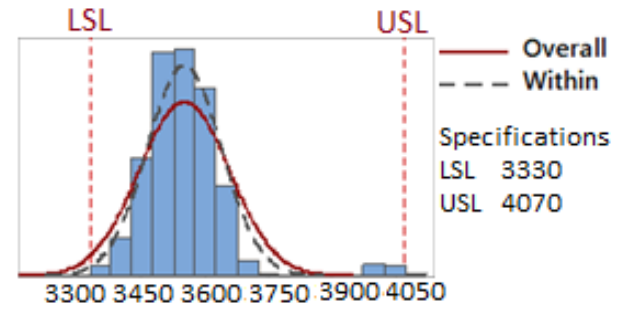

Fig. 8. Process capability graph (current process): Capability histogram

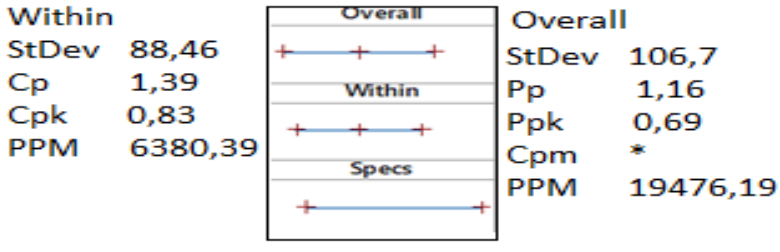

Fig. 9. Process capability graph (current process): Apability plot

Process capability ratio is $C_{p}=1.39(>1.33)$ which indicates that our process distribution is accurate, but process capability index is $C_{p k}=0.83$ $(<1.33)$ which means that process distribution is not precise (there is shifting of the normal distribution off-center).

Six Sigma (DMAIC) - Analyze phase: Cause \& Effect matrix is shown in Table 3, with categorizing causes with the highest probability to turn into failure "Resistance out of spec".

Table 3

\section{Cause \& Effect matrix}

\begin{tabular}{|c|c|c|c|}
\hline \multicolumn{2}{|c|}{ Rating of importance to customer >> } & \multirow{2}{*}{ 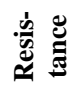 } & \multirow{2}{*}{ है } \\
\hline Process step & Process inputs & & \\
\hline $\begin{array}{l}\text { Sewing } \\
\text { process }\end{array}$ & $\begin{array}{l}\text { Number of hit wire per meter by } \\
\text { needle during sewing out of spec. }\end{array}$ & 9 & 90 \\
\hline $\begin{array}{l}\text { Sewing } \\
\text { process }\end{array}$ & $\begin{array}{l}\text { Operator handling NOK } \\
\text { (wire/thread tension NOK, wrong } \\
\text { parameter on feeding device). }\end{array}$ & 9 & 90 \\
\hline $\begin{array}{l}\text { Crimping } \\
\text { process }\end{array}$ & $\begin{array}{l}\text { Operator handling NOK (posi- } \\
\text { tioning I-Cu wire). }\end{array}$ & 9 & 90 \\
\hline Welding & Missed welding process. & 9 & 90 \\
\hline $\begin{array}{l}\text { Incoming } \\
\text { inspection }\end{array}$ & & 3 & 30 \\
\hline $\begin{array}{l}\text { Incoming } \\
\text { inspection }\end{array}$ & $\begin{array}{l}\text { Condition of wire from supplier } \\
\text { (Damaged wire). }\end{array}$ & 3 & 30 \\
\hline $\begin{array}{l}\text { Sewing } \\
\text { process }\end{array}$ & $\begin{array}{l}\text { ed heating wire during } \\
\text { rewinding process before }\end{array}$ & 3 & 30 \\
\hline $\begin{array}{l}\text { Sewin } \\
\text { proce }\end{array}$ & & 3 & 30 \\
\hline Pre-assembly & $\begin{array}{l}\text { Operator handling (manual cut, } \\
\text { pull out the wire). }\end{array}$ & 3 & 30 \\
\hline Pre-assembly & $\begin{array}{l}\text { Tools and working conditions } \\
\text { NOK. }\end{array}$ & 3 & 30 \\
\hline Pre-assembly & $\begin{array}{l}\text { condition of seat heater } \\
\text { wing NOK. }\end{array}$ & 3 & 30 \\
\hline Stripping proc. & Strip & 3 & 30 \\
\hline $\begin{array}{l}\text { Stripping } \\
\text { process }\end{array}$ & $\begin{array}{l}\text { Operator handling NOK (wire } \\
\text { positioning). }\end{array}$ & 3 & 30 \\
\hline $\begin{array}{l}\text { Welding } \\
\text { process }\end{array}$ & $\begin{array}{l}\text { Operator handling NOK (posi- } \\
\text { tioning of the wire, supporting } \\
\text { wire during welding). }\end{array}$ & 3 & 30 \\
\hline Welding proc. & $\begin{array}{l}\text { Welding machine parameters } \\
\text { NOK }\end{array}$ & 3 & 30 \\
\hline FA line & MSA of the EOL tester NOK. & 3 & 30 \\
\hline FA line & Probe pins on EOLT worn-out. & 3 & 30 \\
\hline Crimping proc. & Crimp tool worn-out. & 1 & 10 \\
\hline Total & & 76 & \\
\hline
\end{tabular}


Based on daily failure analyses conducted in period of 1 year, root causes of the failure are categorized: In 39\% (from total 6.400 ippm), root cause is needle hit wire - sewing process.

1) In $28 \%$ (from total $6.400 \mathrm{ippm}$ ), root cause is deviation of wire consumption - sewing process.

2) In $16 \%$ (from total $6.400 \mathrm{ippm}$ ), root cause is wrong positioning of the heating wire $\&$ harness - crimp process.

3) In 9\% (from total $6.400 \mathrm{ippm}$ ), root cause is skipped welding process - FA line. failure.

4) In $8 \%$ other reasons are root cause of the

Six Sigma (DMAIC) - Improve phase: As corrective action for the root causes of the failure resistance out of spec we have implemented inteligent automation. Intelligent automation introduce some supervisory functions rather than production functions of the machines.

1. Sewing process: a) Automated hit wire detection system. The system will implement 100\% detection of the damaged wire, and will implement in station quality control. NOK parts will not proceed to the next process. Additionally, the system will stop the sewing machine and root cause analysis can be immediately carried out (wrong thread/wire tension, needle high miss adjustment etc.). Electrical scheme is presented in Figure 10. b) System for checking if the hit wire detection system is activated. When heating wire is not connected with the feeder system than hit wire detection system is not activated, and the failure will not be detected. PLC system was installed which will automatically check and validate the accuracy of the connection. c) Automated system for control the consumption of heating wire. On each feeder system was installed encoder, connected to the PLC which will measure wire consumption and compare with bill of material of that specific product. If wire consumption deviate from BOM, machine will stop and operator will investigate the root cause of the deviation.

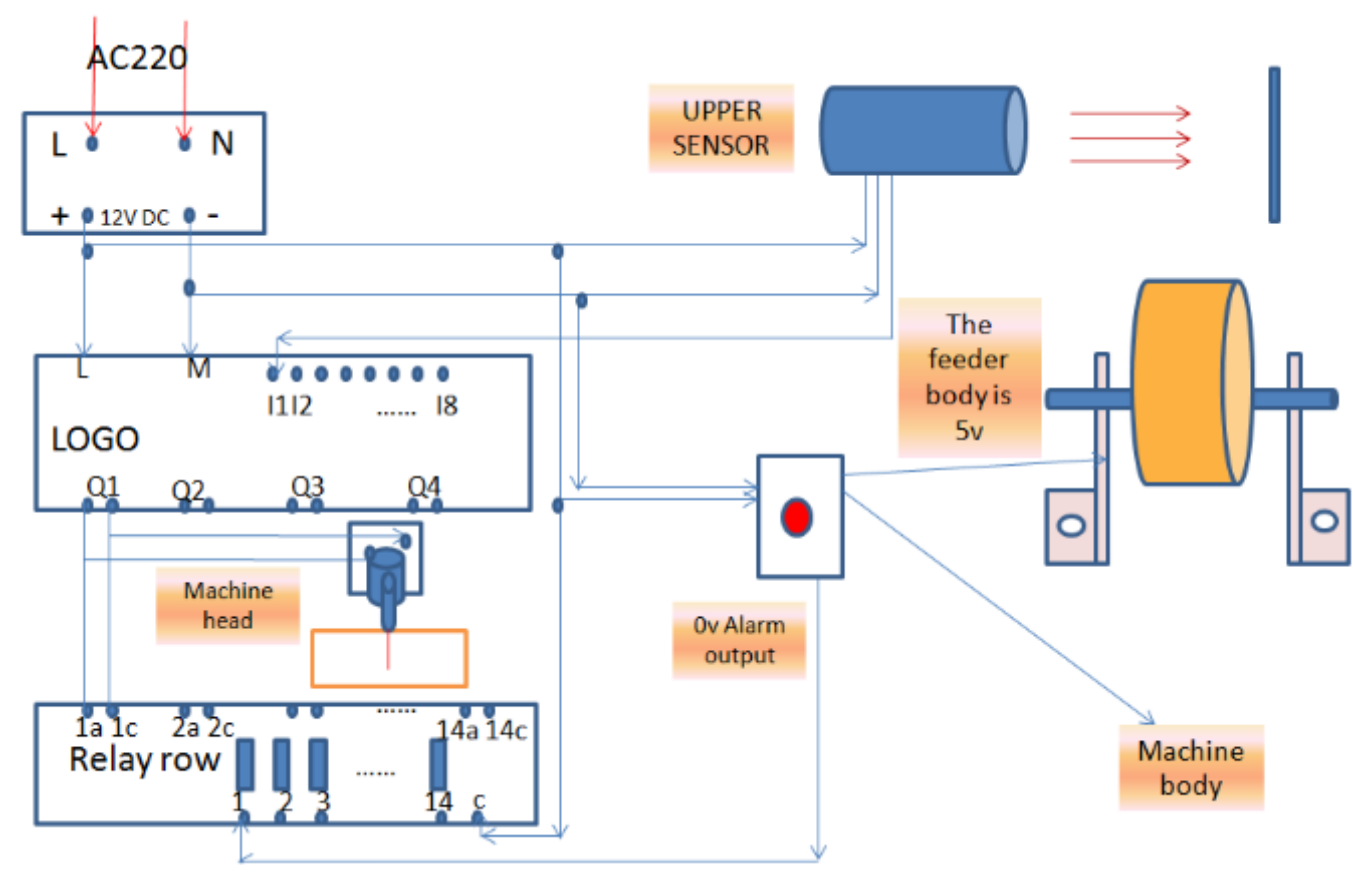

Fig. 10. Electrical wiring of the needle hit detection (System)

2) Crimping process - System for controlling heating wire position. Camera system was installed on crimping machine to monitor and control position of wire.

3) Final assembly line - System for controlling sequence of processes on FA line. Due to rotation mode and manual assembly process in the final assembly line, sometimes operatorss miss some of the assembly processes. PLC controller was installed to control the sequence of the assembly processses and avoids operator mistake.

Process capability study was performed after implementation of all process improvements. The study was carried out with 400 measured samples. 
Six Sigma (DMAIC) - Control phase: For sustainability of achieved results were done following updates: PFMEA, control plan, drafting process procedure, training, calculation of process capability and control gate review.

4. The results and discussion - For validation effectiveness of the implemented Six Sigma DMAIC methodology we will compare individual chart I, moving range chart MR, process capability and process performance before and after implemented improvements (see Figure 9 vs. Figure 14). With eliminating special causes, $C$ is almost identical to $P$.

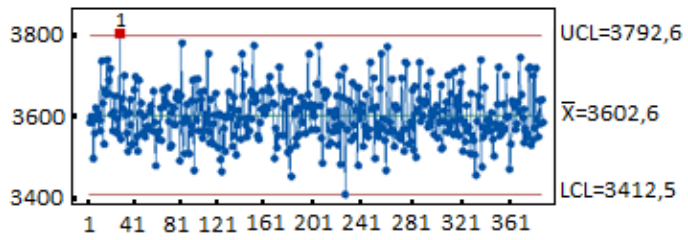

Fig. 11. Process capability graph (after improvements): I chart (individual value)

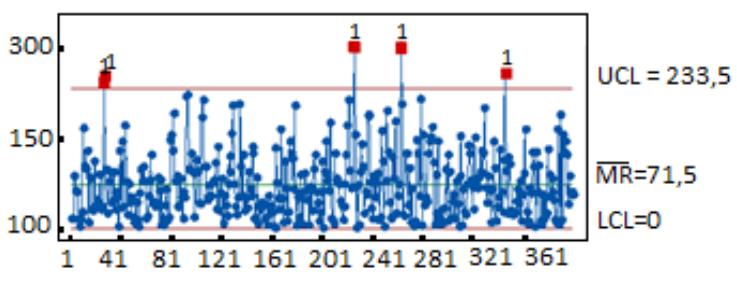

Fig. 12. Process capability graph (after improvements): Moving range chart

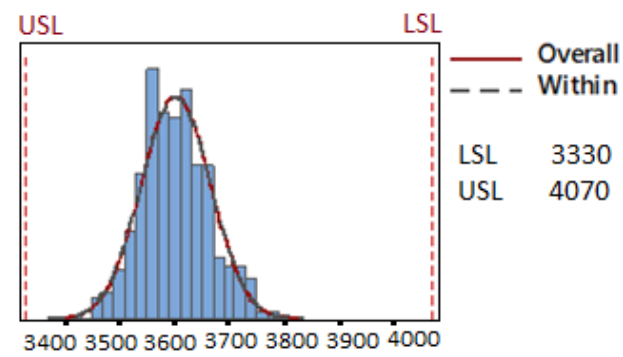

Fig. 13. Process capability graph (after improvements): Capability histogram

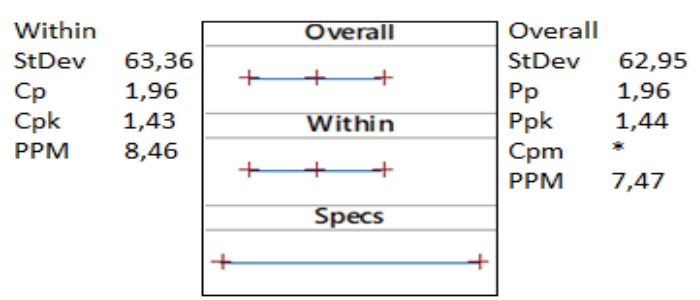

Fig. 14. Process capability graph (after improvements):Capability plot
Table 4

Process capability and performance before vs. after process improvements

\begin{tabular}{cccc}
\hline \hline & $\begin{array}{c}\text { Before } \\
\text { improvements } \\
\text { in the process }\end{array}$ & $\begin{array}{c}\text { After } \\
\text { improvements } \\
\text { in the process }\end{array}$ & $\begin{array}{c}\text { Before vs. } \\
\text { after } \\
(\%)\end{array}$ \\
\hline$\dot{\mathrm{C}}_{p}$ & 1.39 & 1.95 & 40 \\
$\dot{\mathrm{C}}_{P_{k}}$ & 0.83 & 1.43 & 72 \\
$\dot{\mathrm{P}}_{p}$ & 1.16 & 1.96 & 69 \\
$\dot{\mathrm{P}}_{p_{k}}$ & 0.69 & 1.44 & 109 \\
\hline \hline
\end{tabular}

This improvement of process capability is significant and it is validation of the successful implementation of Six Sigma project in automotive company for seat heaters production.

\section{CONCLUSION}

In the present work, initiative has been taken to apply Six Sigma in automobile sector manufacturing company to reduce the level of defects.

The application of Six Sigma DMAIC model helped in quick root cause analysis and reduction of rejection and improvement of process capability from $C_{P_{k}}=0.83$ to $C_{P_{k}}=1.43$, and 235,000 cost savings in period of 1 year.

Even though this is a small research work it can be certainly concluded that, Six Sigma is really a tool that can be used to obtain positive results in process improvements. If the methodology is applied through all the production lines, it would be very beneficial for the company as it would result in significant saving of resources.

\section{REFERENCES}

[1] Singh, A. K., Khanduja, D.: Defining quality management in auto sector: Six Sigma percetion. International Conference in Advances in Manufacturing and Materials Engineering ICAMME, 2014.

[2] Kumar, S.: Application of Six Sigma in automobile industry. International Journal of Exploration in Engineering and Technology (IJEET), 2, 1 (2016).

[3] Sarkar, A., Mukhopadhyay, A. R., Ghosh, S. K.: Improvement of claim processing cycle time through lean Six Sigma methodology. International Journal of Lean Six Sigma, 4 (2), 171-183 (2013).

[4] Antony, J., Banuelas, R.: Key ingredients for the effective implementation of Six Sigma program. Measuring Business Excellence, 6 (4), 20-27 (2002).

[5] Ike Ehie and ChwenSheu: Integrating six sigma and theory of constraints for continuous improvement: a case study, 
Journal of Manufacturing Technology Management, Vol. 16, Iss. 5, pp.542-553 (2005) .

[6] Maha, M. Y., Abdul, R. O., Sany, S. M. M.: Six Sigma and innovation performance: A conceptual framework based on the absorptive capacity theory perspective, International Journal of Emerging Science, Vol. 1, No. 3, 307-323 (2005).

[7] Antony, J., Sence, R., Hoerl, R.: Lean Six Sigma: yesterday, today and tomorrow. International Journal of Quality \& Reliability Management, 34, 7, 1073-1093 (2017).

[8] Chaczko, Z., Rahali, E., Tariq, R.: The application of Six Sigma to integration of computer based systems, Journal of Business, Human and Social Sciences, 0.0 (10), World Ac. (2007), http://doi.org/10.5281/zenodo.1328374.

[9] Bewoor, A. K., Pawar, M. S.: Mapping macro/micro level critical links for integrating Six Sigma DMAIC steps as a part of company's existing QMS: an Indian SME case study, International Journal of Six Sigma and Competitive Advantage, Vol. 6, No. 1-2, pp. 105-131 (2010).

[10] Six Sigma Green Belt, Training materials Gentherm .

[11] Dreachslin, J. L., Lee, P. D.: Applying Six Sigma and DMAIC to diversity initiatives. Journal of Healthcare Management, Vol. 52, Iss. 6, pp 361-367 (2007).

[12] Stamatis, D. H.: Six Sigma Fundamentals: A Complete Guide to the System, Methods and Tools". Productivity Press, New York (2007.
[13] Omachonu, V. K., Ross, J. E.: Principles of Total Quality. CRC Press, 2004.

[14] Measurement System Analysis (MSA), part of IATF 16949.

[15] Statistical Process Control (SPC), part of IATF 16949

[16] Pyzdek, T., Keller, P. A.: The Six Sigma Handbook, Fourth edition. McGraw-Hill Education, 2014).

[17] Adams, C., Gupta, P., Wilson, C.: Six sigma deployment, Routledge (2014).

[18] Garza-Reyes, J. A., Oraifige, I., Soriano-Meier, H., Harmanto, D., Rocha-Lona, L.: An empirical application of Six Sigma and DMAIC methodology for business process improvement. Proceedings of the 20th International Conference on Flexible Automation and Intelligent Manufacturing (FAIM), 92-100. San Francisco, CA, 2014.

[19] Failure Mode and Effects Analysis (FMEA), part of IATF 16949.

[20] Breyfogle. III, F. W., Cupello, J. M., Meadows, B.: Managing Six Sigma: A Practical Guide to Understanding, Assessing, and Implementing the Strategy that Yields Bottom-line Success. John Wiley \& Sons. 2000.

[21] Benbow, D. W., Kubiak, T. M.: The Certified Six Sigma Black Belt Handbook. ASQ Quality Press, Milwaukee [22] Advance Product Quality Planning and (APQP) and control plan, part of IATF 16949. 2005.

Table A.1

\section{A P P E N D I X}

Gage repeatability and reproducibility report sheet

\begin{tabular}{|c|c|c|c|c|c|c|c|c|c|c|c|c|c|}
\hline & \multirow{2}{*}{$\begin{array}{c}\text { Appraises? } \\
\text { Trails \# } \\
\end{array}$} & \multicolumn{10}{|c|}{ PART } & \multicolumn{2}{|c|}{ AVERAGE } \\
\hline & & 1 & 2 & 3 & 4 & 5 & 6 & 7 & 8 & 9 & 10 & & \\
\hline & 1 & 3502 & 3441 & 3539 & 3369 & 3455 & 3517 & 3483 & 3382 & 3337 & 3409 & & 3443,4 \\
\hline 2 & 2 & 3514 & 3439 & 3533 & 3375 & 3466 & 3524 & 3482 & 3390 & 3345 & 3417 & & 3448,5 \\
\hline 3 & 3 & 3507 & 3446 & 3544 & 3374 & 3461 & 3522 & 3487 & 3389 & 3341 & 3415 & & 3448,6 \\
\hline 4 & Average & 3508 & 3442 & 3539 & 3373 & 3461 & 3521 & 3484 & 3387 & 3341 & 3414 & $\overline{X_{a}}=$ & 3447 \\
\hline 5 & Range & 12 & 7 & 11 & 6 & 11 & 7 & 5 & 8 & 8 & 8 & $\overline{R_{a}}=$ & 8300 \\
\hline 5 & B & 3519 & 3454 & 3548 & 3379 & 3468 & 3527 & 3494 & 3393 & 3347 & 3420 & & 3454.9 \\
\hline 7 & 2 & 3504 & 3451 & 3546 & 3369 & 3466 & 3517 & 3488 & 3383 & 3339 & 3418 & & 3448.1 \\
\hline 8 & 3 & 3512 & 3448 & 3541 & 3375 & 3461 & 3523 & 3487 & 3389 & 3341 & 3415 & & 3449.2 \\
\hline 9 & Average & 3512 & 3451 & 3545 & 3374 & 3465 & 3522 & 3490 & 3388 & 3342 & 3418 & $\overline{X_{b}}=$ & 3451 \\
\hline 0 & Range & 15 & 6 & 7 & 10 & 7 & 10 & 7 & 10 & 8 & 5 & $\overline{R_{b}}=$ & 8500 \\
\hline 1 & 1 & 3514 & 3444 & 3540 & 3376 & 3460 & 3523 & 3490 & 3387 & 3342 & 3421 & & 3449.7 \\
\hline 2 & 2 & 3500 & 3455 & 3548 & 3381 & 3457 & 3526 & 3494 & 3394 & 3347 & 3416 & & 3451.8 \\
\hline 3 & 3 & 3512 & 3448 & 3544 & 3375 & 3462 & 3528 & 3487 & 3390 & 3349 & 3412 & & 3450.7 \\
\hline 4 & Average & 3509 & 3449 & 3544 & 3377 & 3460 & 3526 & 3490 & 3390 & 3346 & 3416 & $\overline{X_{c}}=$ & 3451 \\
\hline 5 & Range & 14 & 11 & 8 & 6 & 5 & 5 & 7 & 7 & 7 & 9 & $\overline{R_{C}}=$ & 7900 \\
\hline 6 & Part Average & 3509 & 3447 & 3543 & 3375 & 3462 & 3523 & 3488 & 3389 & 3343 & 3416 & $\begin{array}{r}\overline{\bar{X}}= \\
R_{p}=\end{array}$ & $\begin{array}{c}3449 \\
199 \\
\end{array}$ \\
\hline & \multicolumn{11}{|c|}{$\left(\left[\overline{R_{a}}=8.3\right]+\left[\overline{R_{b}}=8.5\right]+\left[\overline{R_{c}}=7.9\right] /[\right.$ OFF APPRAISERS $\left.=3]\right)=$} & $\overline{\bar{R}} \mathrm{a}$ & 8.23 \\
\hline & \multicolumn{11}{|c|}{$[\operatorname{Max} \bar{X}=3.451]-[\operatorname{Min} \bar{X}=3447]=\bar{X}_{D I F F}=0.004$} & & \\
\hline 9 & \multicolumn{11}{|c|}{$[\overline{\bar{R}}=8.23] X\left[D_{4}=2.58\right]=U C L_{R}=21.2$} & & \\
\hline & \multicolumn{11}{|c|}{$\mathrm{D}_{4}=2.58$ for 3 trials. $\mathrm{UCL}_{\mathrm{R}}=$ represent the limit of individual $R$ 's } & & \\
\hline
\end{tabular}


Table A.2

Gage repeatability and reproducibility report sheet

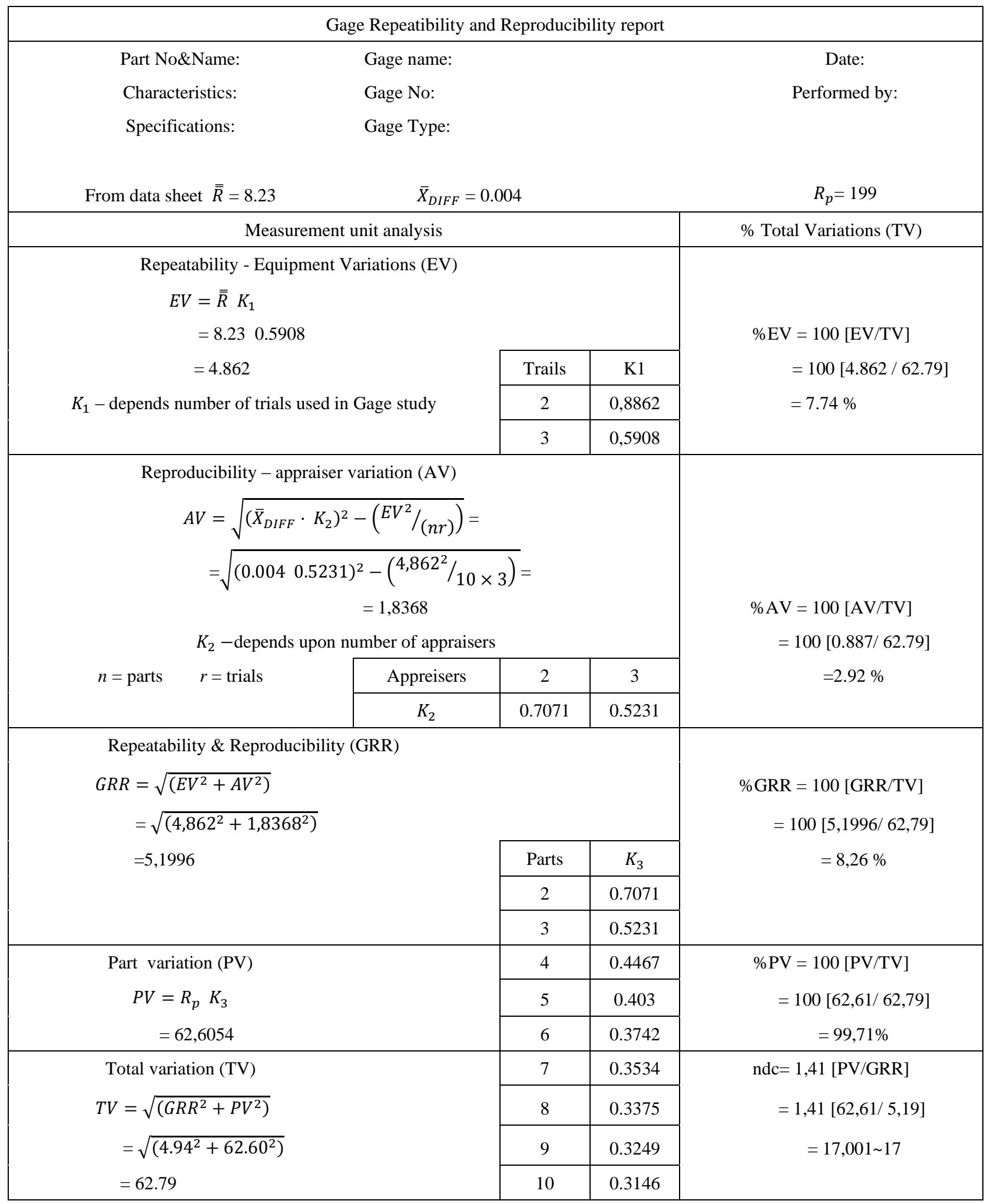


